By FRED WALDECK

\title{
Adolph Sutro's Lost Library
}

$\mathrm{W}$

HEN THE FLAMES in the wake of the great San Francisco earthquake of 1906 wiped out the major part of the Sutro Library with its thousands of incunabula, the world of culture sustained a tragic and irreparable loss. The brilliant life of its founder, Adolph Heinrich Sutro, builder of the Sutro tunnel through the Comstock Lode, mayor of San Francisco, and philanthropist, is part of the romantic tradition of "the Queen of the Pacific." With his ambitious project to create a vast, free library, a research center for scholars of the West Coast, the one-time immigrant made an outstanding contribution to the cultural life of his adopted country.

In 1877 Sutro began to devote all his time to the acquisition of his book collection and went about this task with the same sweeping energy that brought him success against all odds in the construction of the tunnel. Known as "the California bookman" in London book circles, he personally bought more than 50,000 volumes of his collection, while his agents were to be found wherever important book auctions took place in Europe and Mexico. The selection of his books "made at a favorable time and under fortunate and extraordinary circumstances" 1 reflected his interest in pure and applied science and in the art of printing.

The Bayrische Staatsbibliothek in Munich had absorbed the libraries of all the confiscated monasteries of Bavaria in the

1 Adolph Sutro, San Francisco, California, Letter to the Regents of the University of California . . on the selection of a site for the affiliated colleges, September 5, 1895 (University of California Library, Berkeley, California).

$M r$. Waldeck is a reference librarian, History Division, Oakland, Calif., Public Library. beginning of the nineteenth century, resulting in much duplication of rare incunabula. Sutro's agents succeeded in purchasing more than 3,000 incunabula, approximately 7 per cent of all extant works of the early printing presses. Several libraries of distinction came under the hammer and were bought outright by Sutro. The first one to be sold at auction was the library of the Carthusian monastery at Buxheim, near Memmingen, Bavaria. The treasures of this ancient monastery, secularised in the $\mathrm{Na}$ poleonic era, were auctioned by the heir of a wealthy aristocrat in satisfaction of a debt. Large purchases were made from the library of Baron Wolfgang Heribert von Dalberg, which was strong in history, geography, and the fine arts. Other important libraries bought outright were the Sunderland and Blenheim collections belonging to the Duke of Marlborough and the books owned by the Duke of Hamilton. Other interesting acquisitions were the documents and pamphlets of Lord Macaulay which constituted his source material for his great history of England.

Adolph Sutro mentioned also his purchases of the codified laws of England from the library of Lord Cairns and the science collection of the Secretary of the London Chemical Society. In 1892, Professor Burr of Cornell praised the Sutro Library's holdings of Renaissance and Reformation material and claimed that it had no rivals in the United States for its literature of the sixteenth century. ${ }^{2}$ At that time the Sutro Library comprised more than a quarter of a million volumes. It was said to be one of the largest private libraries in America. Sutro worked tirelessly to enlarge it with

2 M. J. Ferguson, "The Sutro Library," News Notes of California Libraries, VIII (1913), 445-47. 
thousands of new acquisitions. He employed a dozen "catalogers" of a sort who were forever hopelessly in arears and only able to make a fraction of the material accessible. A regiment of binders did a rush job not always in accordance with modern binding principles. When the library building in Battery Street was filled to capacity with 200,000 books, including most of the incunabula, the overflow of the remaining 100,000 volumes was stored in the historic Montgomery Block.

Sutro's untimely death in 1898 prevented the realization of his plans for further expansion of the library and an adequate library building. Then followed years of stagnation while his estate became entangled in litigation. The great holocaust in the wake of the earthquake of April, 1906, destroyed the Battery Street building and reduced to ashes most of the incunabula and the greater part of the collection. Sutro's daughter, Dr. Emma Merritt, personally salvaged the Shakespeare folios. Miraculously, the Montgomery Block, containing the 100,000 volumes, escaped the fire. However, some rare books were damaged by looters who tore out pages to wrap up stolen tobacco and cigars.

In 1913, the Sutro heirs donated this still impressive collection to the State of California. It became a branch of the California State Library, housed in the San Francisco Public Library building.

A bibliographic search for rarities in the lost Sutro Library was greatly facilitated by the discovery of a card box marked: "Incunabula destroyed in the Fire." Richard Dillon, Sutro's versatile author-librarian, found this handwritten short-title catalog gathering dust in the basement. After a perusal of this list, the following interesting items were noted:

A fine example of one of the earliest books printed with cast metal type, Guilelmus Durandus, Rationale divinorum officiorum (Mainz, Johann Fust and Peter Schoeffer, 1459). The Rationale is one of the authoritative works on Roman Catholic liturgy.

The monumental work of Vincentius Bellovacensis, Speculum historiale (Augsburg, 1476), Vincentius Bellovacensis (c 1190-ca 1264), also known as Vincent de Beauvais, was the outstanding encyclopedist of the thirteenth century. The library also owned his Speculum naturale, a vast summary of all the natural sciences known to western Europe towards the middle of the thirteenth century. This work was divided into 32 books and 3,718 chapters.

The varied nature of the collection may be further illustrated by such works as the complete writings of Giovanni Pico della Mirandola, the great humanist and leading scholar of the Italian Renaissance, Joannis Pici Mirandulae, $\mathrm{Om}$ nia Opera (Venice, /1498); and Jean Charlier de Gerson, Opera (1480). Jean de Gerson was the prominent chancellor of the University of Paris in the fourteenth century.

Among the scientific works may be mentioned the book of the fifteenthcentury mathematician and astronomer, Johannes Baptista Abiosus, Dialogus in astrologiae defensionem (Venice, Lapicida, 1494; Hain 24).

Another notable item was the work of one of the most learned scholastic philosophers of the thirteenth century, Albertus Magnus, Liber de muliere forti (Cologne, Heinrich Quentell, 1499; Hain 465).

In the field of law there were incunabula such as Justianus, Corpus juris civilis (Venice, 1477). This codex is the basis of virtually all continental European law.

The collection contained also the famous work of the early Christian church father Saint Augustine, De civitate dei (Basel, J. Amerbach, 1490).

There were many editions of the classics, including: Aristoteles, Opera (Augsburg, A. Keller, 1479; Hain 1658); Dyonysus Cato, Ethica (Augsburg, A. Sorg, 1475) ; Strabo, De situ orbis (Ven- 
ice, 1494); Suetonius, Vitae duodecim Caesarum (Bonn, Bervaldi, 1493) .

Over two hundred and fifty copies were first editions. ${ }^{3}$ Among the incunabula were many important works from the earliest printing presses of various cities, such as Gunther Zainer, Sorg, and Froschauer of Augsburg; Fust and Schoeffer of Mainz; Zarotus of Milan; Koberger and Sensenschmidt of Nuremberg; Planck and Pannartz of Rome; Peter Drachen of Speyer; Eggesteyn of Strasbourg; and Aldus Manutius of Venice.

Not more than forty incunabula were saved. One of them, the letters of St. Jerome, printed by Peter Schoeffer in 1470 , is a noteworthy example of the early art of printing. One of the earliest items in the collection is a Gerson, printed by Ulrich Zell, Cologne, in 1464. One may also examine a well preserved Nuremberg Chronicle, printed in 1496, and a St. Thomas Aquinas, published in 1478.

The library still contains several notable Renaissance bibliographies such as Theodorus Janssonius ab Almeloveen, De vitis Stephanorum celebrium typographorum (Amsterdam, 1683).

The destruction did not spare a unique collection of Bibles which included such rarities as a German Bible printed by Eggesteyn at Strasbourg about 1466; the Plantin of Antwerp Polyglot of 1569, printed in Hebrew, Chaldean, Greek and Latin; the "Vinegar" Bible; and the Puritan favorite, the Geneva Bible, published in 1615 .

Twenty-nine large folios, the work of the classical scholars Johann Georg Graevius and Johann Friedrich Gronovius on Greek and Roman antiquities, burned to ashes together with 64 volumes of Zedler's Grosses vollstaendiges Universal-Lexikon, published in 1732-50, one of the great encyclopedias of the eighteenth century. More extensive re-

3 "Notes on the Sutro Library," Overland Monthly, V (1885), 616-617. search based on the examination of the Sutro letters in the Bancroft Library may disclose additional material lost in the fire.

A brief survey of some of the resources of the Sutro's present collection might also be an aid in identifying the holdings of the original library. In the pages of the Sutro Library Notes, edited by Richard Dillon, much important research material is highlighted. The following are particularly noteworthy:

The sixteenth century is well represented by many Martin Luther items such as: Ein Brief an den Cardinal Erzbischof zu Mainz (Nuremberg, 1530); Ein Brief an die zu Frankfort am Meyn (Wittenberg, 1533). There is also much sixteenth-century material on the Catholic Church in Spain and Mexico. The library has a fine copy of Jan Huss, De anatomia Antichristi. Opuscula (1522). There is also a beautiful edition of Benedette Bordoni, Isolario (Venice, 1547) with many engraved maps. The Sutro Library is very fortunate in possessing a copy of Ordenãças y compilación de leyes (Mexico, 1548), the work of the first printing press in the Americas, by Antonio de Mendoza, the first Viceroy of New Spain. The New York Public Library has the only other copy.

With the en bloc purchase of the Sunderland Library, Sutro acquired a unique collection of seventeenth-century broadsides, pamphlets, and other important material relating to the English Civil War and the Commonwealth periods, Cromwell and the Stuarts. This mine of information is still available to scholars visiting the library. The Catalogue of Mexican Pamphlets in the Sutro Collection (1623-1887) prepared by the personnel of the WPA describes the particularly strong holdings of documents relating to the history of Mexico and the Pacific Coast.

Reflecting Adolph Sutro's scholarly interests, much source material on the sciences and the history of science has been 
collected and made available in the Library. Among the many interesting manuscripts are 200,000 papers and letters of Sir Joseph Banks who for many years was president of the Royal Society and a companion of Captain Cook, the explorer. ${ }^{4}$

The art student will appreciate the fine Hokusai and Hiroshige Japanese prints. The important Hebrew section contains some lovely scrolls, a Yemenite manuscript of the Middle Ages, allegedly a Maimonides manuscript, books of the

"Richard H. Dillon, "A Peek at Sutro Library," Book Club of California Quarterly News Letter, XVII (1952), 27-32. fifteenth century, and some beautiful examples of the work of the Elzevirs. ${ }^{5}$ In the field of philosophy, interest focuses on the eighteenth-century editions of Immanuel Kant, printed in Königsberg.

Despite the heavy losses sustained in the Fire, the resources of the Sutro Library are, as this brief review indicates, still of considerable importance to scholarship. It is, therefore, gratifying to note that increasing use is made of the library by professors, students, writers, and the general public.

'Michael Zarchim, Glimpses of Jewish Life in San Francisco. San Francisco: 1952, pp. 31-34.

\section{Meeting on Depository System at Midwinter}

The Committee on Public Documents will sponsor an open meeting at the Edgewater Beach Hotel on Tuesday, January 29, at 10:00 A.M., to encourage discussion of depository libraries for U. S. government publications and the changes which should be made in the legislation under which they now operate.

The Subcommittee to Study Federal Printing and Paperwork of the Committee on House Administration has just distributed to depository and non-depository libraries a questionnaire which inquires into the effectiveness of the present depository system. These questions were prepared with the assistance of the ALA Committee on Public Documents and should provide much of the data needed in rewriting existing legislation. The questionnaire should stimulate thinking and suggest questions concerning documents and their distribution which can be discussed at the meeting.

\section{Florida Graduate Assistantships}

The University of Florida Libraries is offering three graduate assistantships in the academic year 1957-58 for study leading to a master or doctoral degree in a subject field other than library science. Graduate assistants work approximately 15 hours per week in the Library, assisting in bibliographical research or library administration.

Stipend is $\$ 1,400$ for a nine month period and holders of assistantships are exempt from out-of-state tuition fees. The deadline for filing formal application is March 31, 1957.

Inquiries are invited, especially from libraries or students in library schools who are interested in advanced work in subject fields. Applications should be made to: Director of Libraries, University of Florida, Gainesville, Florida. 